\title{
Agricultural Extension, Plant Breeder, and Plant Researcher Animation Video
}

\author{
Walidatush Sholihah ${ }^{1}$, Sascorio Ade Akbar ${ }^{2}$ \\ ${ }^{1}$ Computer Engineering, Vocational School, Bogor Agricultural University \\ ${ }^{2}$ Informatics Management, Vocational School, Bogor Agricultural University \\ *E-mail: sh.walidah@gmail.com
}

\begin{abstract}
An agricultural extension, plant breeder, and plant research animation video was produced to provide information and insights about the agricultural profession to elementary and high school students. Advancing agriculture is the job of the Indonesian Agency for Agricultural Research and Development (IAARD). The video was made in three stages: 1) pre-production, or planning; 2) production, or the actual making of the video; and 3) post production, the final refining stage. The pictures used in this video were taken from www.freepik.com and reprocessed (by tracing) before being used in the video. The software programs used to make the video were Adobe After Effects and Sony Vegas Pro. The video's duration is three minutes and 11 seconds. The video's scenes are colorful and cheerful. A video preview can be viewed on IAARD's Instagram account and the full video can be seen on www.youtube.com. The video is also shown during student visits at IAARD's agrocinema building in Bogor.
\end{abstract}

Keywords: agricultural extension, animation, plant breeder, plant researcher, video

\section{Introduction}

Agricultural extension, plant breeding, and plant research are the three most important components of advancing agriculture in Indonesia. Agricultural extension activities are a continuous process for delivering useful information and technology to farmers and their families (Bestina, Hartono, \& Syam, 2005). An agricultural extension expert can be interpreted as a facilitator in charge of providing knowledge and insights for farmers to increase food production. In addition, agricultural extension also serves as a bridge between the government and farmers.

Plant breeding entails a series of research and testing activities for the discovery and development of plant varieties in accordance with standard methods for producing new varieties and maintaining the purity of their seeds. The standards are based on Government Regulation of the Republic of Indonesia Number 13 of 2004 concerning the naming, registration, and use of original plant varieties for the manufacture of essential derived varieties (Republic of Indonesia, 2004). A plant breeder is a specialist who conducts plant breeding activities with the aim to improve their genetic quality. Professor Surjono Hadi Sutjahjo of Bogor Agricultural University (IPB) Faculty of Agriculture has said that Indonesia lacks sufficient plant breeding experts to produce new varieties of agriculture (Putra, 2016).

According to the Regulation of the Head of the Indonesian Institute of Sciences number 1 of 2016 on the Guidance on Selection of Expert Fields of Researchers, researchers are those with recognized expertise in a scientific field and are in charge of scientific and technological research and / or development (Indonesian Institute of Sciences (LIPI), 2016). Plant breeders are also researchers; however, their work is specialized to develop new varieties.

The number of agricultural extension experts, breeders, and plant researchers is still limited in Indonesia, an agrarian country, due to the lack of young people's knowledge of the profession and concerns that the profession's earnings are less secure for the future. The young generation in Indonesia needs to be given knowledge and insights about agricultural extension, plant breeding, and research careers so that agriculture can better develop in the country.

Members of the young generation of today tend to engage with what they can see and hear at the same time. Animated videos are a form of media that can deliver information that can simultaneously be seen and heard. Video is a moving image. In addition to pictures, a video also has sound. Information conveyed via video can be seen and heard. An animated video is a video that contains animated images. Cartoon is the form of animation used in the case of this video. Animated videos are easy to watch and suitable for all ages.

The Indonesian Agency for Agricultural Research and Development (IAARD), Ministry of Agriculture is a research institution that produces and develops modern agricultural technology with the aim of achieving high productivity and efficiency. In addition to conducting agricultural research, IAARD is also tasked with disseminating research results. Located in Bogor, IAARD is often visited by students from the elementary to high school levels. IAARD has a showroom building that exhibits research results as well as an agrocinema, 
which is a movie showroom geared with a projector and widescreen. Among the information that IAARD wants to convey to students is knowledge about agricultural extension workers, breeders, and plant researchers, which is presented in the agrocinema in the form of animated videos. The animated video described herein was produced in a collaboration between IPB University Vocational School and IAARD.

\section{Methods}

The agricultural extension, plant breeder, and plant researcher animation video was made in three stages, namely pre-production, production, and post production. The stages can be seen in Figure 1.

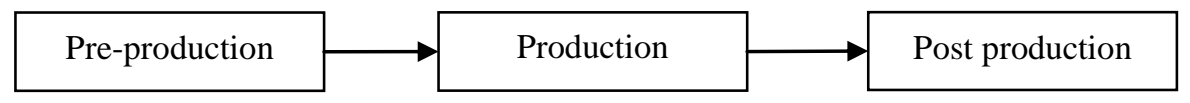

Fig. 1. Animation video methods

The pre-production stage is the planning stage. There are several things that must be determined at this point of the process, including the target audience, the duration of the video, the information to be conveyed, and the storyline. The target audience for our agricultural extension, plant breeder, and plant researcher animation video is elementary and high school students. Students can easily absorb information presented in a colorful and cheerful video. Since this video will be aired in Indonesia, the language used is the Indonesian language. The animation video's duration video is approximately three minutes. The information is presented in a storyline, which comprises the video's plot in narrative form. Table 1 presents the storyline of our animation video.

Table 1. Storyline of the animation video

\begin{tabular}{|c|c|c|c|}
\hline Story & & Visual & Audio \\
\hline Opening & $\begin{array}{l}\text { Bitmap } \\
\text { Vector } \\
\text { Text }\end{array}$ & $\begin{array}{l}\text { :- } \\
\text { : farmer's character } \\
\text { : "Profesi Pertanian," } \\
\text { "Peluang Karir Masa } \\
\text { Depan", }\end{array}$ & $\begin{array}{l}\text { Back sound: - } \\
\text { Sound effect: - } \\
\text { Narration: - }\end{array}$ \\
\hline $\begin{array}{l}\text { Agricultural job } \\
\text { information: agricultural } \\
\text { extension (penyuluh), plant } \\
\text { breeder (pemulia) and plant } \\
\text { researcher (peneliti) }\end{array}$ & $\begin{array}{l}\text { Bitmap } \\
\text { Vector } \\
\text { Text }\end{array}$ & $\begin{array}{l}\text { :- } \\
\text { : Indonesian map, farmer, } \\
\text { logos } \\
\text { :Pertanian, Petani, } 3 \\
\text { Profesi Pertanian, Pemulia, } \\
\text { Peneliti, Penyuluh" }\end{array}$ & $\begin{array}{l}\text { Narration: Tau gak, di Indonesia, dalam } \\
\text { dunia pertanian, profesinya tidak hanya } \\
\text { petani saja lhoo..., hah masa sihh? Iya, } \\
\text { dalam pertanian, terdapat tiga profesi } \\
\text { yang sangat penting demi kelancaran } \\
\text { pertanian, yakni pemulia, peneliti, dan } \\
\text { penyuluh }\end{array}$ \\
\hline $\begin{array}{l}\text { Description of plant } \\
\text { breeders }\end{array}$ & $\begin{array}{l}\text { Bitmap } \\
\text { Vector } \\
\text { Text }\end{array}$ & $\begin{array}{l}: \text { - } \\
\text { : plant breeder, workspace } \\
\text { for plant breeder } \\
\text { : "pemulia" }\end{array}$ & $\begin{array}{l}\text { Narration: Ini namanya Pemulia, } \\
\text { pemulia bertugas memperbaiki mutu } \\
\text { genetik dari sebuah varietas agar lebih } \\
\text { bermanfaat dan bermutu. Singkatnya, } \\
\text { mereka mencari, menghasilkan, dan } \\
\text { merakit varietas unggul dari suatu } \\
\text { keanekaragaman hayati dari hewan } \\
\text { hingga tumbuhan. Contoh kegiatan } \\
\text { pemulia adalah pembenihan holtikutura } \\
\text { atau perkebunan. } \\
\text { Bayangkan bila tidak ada pemulia, } \\
\text { sebuah tumbuhan dengan varietas yang } \\
\text { sama akan musnah pada saat terjadi } \\
\text { bencana. Maka dari itu pemulia ada } \\
\text { untuk menemukan varietas baru yang } \\
\text { memiliki keunggulan produktifitas dan } \\
\text { meningkatkan ketahanan akan } \\
\text { perubahan iklim dan juga hama. }\end{array}$ \\
\hline
\end{tabular}

Continue Table 1 


\begin{tabular}{|c|c|c|c|}
\hline Story & & Visual & Audio \\
\hline $\begin{array}{l}\text { Description of plant } \\
\text { researchers }\end{array}$ & $\begin{array}{l}\text { Bitmap } \\
\text { Vector } \\
\text { Text }\end{array}$ & $\begin{array}{l}\text { :- } \\
\text { : researcher, researcher's room, } \\
\text { molecule } \\
\text { : “peneliti” }\end{array}$ & $\begin{array}{l}\text { Narration: ini namanya peneliti, } \\
\text { merekalah yang melakukan penemuan } \\
\text { inovasi-inovasi terbaru yang nantinya } \\
\text { dimanfaatkan dalam kehidupan } \\
\text { manusia sehari-hari }\end{array}$ \\
\hline $\begin{array}{l}\text { The work of researchers: } \\
\text { nanotechnology }\end{array}$ & $\begin{array}{l}\text { Bitmap } \\
\text { Vector } \\
\text { Text }\end{array}$ & $\begin{array}{l}:- \\
:- \\
: \text { "nanotechnology" }\end{array}$ & $\begin{array}{l}\text { Narration: Contohnya saja } \\
\text { nanoteknologi. Nanoteknologi sendiri } \\
\text { adalah teknik manipulasi atau } \\
\text { rekayasa ukuran untuk berbagai } \\
\text { manfaat dan aplikasi. Satu nanometer } \\
\text { sama dengan seperjuta millimeter. } \\
\text { Nanoteknologi sendiri menggunakan } \\
\text { atom serta molekul sebagai materi } \\
\text { blok pembuatan yang fundamental. }\end{array}$ \\
\hline $\begin{array}{l}\text { Plastic, the result of } \\
\text { nanotechnology }\end{array}$ & $\begin{array}{l}\text { Bitmap } \\
\text { Vector } \\
\text { Text }\end{array}$ & $\begin{array}{l}: \text { - } \\
\text { : plastic packaging, trees, } \\
\text { checklist, coin } \\
\text { :"nanotechnology, canggih, } \\
\text { praktis" }\end{array}$ & $\begin{array}{l}\text { Narration: Hasil dari penelitian } \\
\text { nanoteknologi ini yaitu kemasan atau } \\
\text { wadah pangan yang berbahan baku } \\
\text { ampas jagung dan ampas tapioka, } \\
\text { sangat aman bagi kesehatan dan } \\
\text { tentunya ramah lingkungan. Selain } \\
\text { itu, kemasan ini bisa dimanfaatkan } \\
\text { untuk kemasan mie instan cup yang } \\
\text { diharapkan bisa sebagai pengganti } \\
\text { sterofoam. }\end{array}$ \\
\hline $\begin{array}{l}\text { Description of agricultural } \\
\text { extension }\end{array}$ & $\begin{array}{l}\text { Bitmap } \\
\text { Vector } \\
\text { Text }\end{array}$ & $\begin{array}{l}:- \\
\text { : farmers, village, farm, money } \\
: \text { "penyuluh" }\end{array}$ & $\begin{array}{l}\text { Narration: dan ini namanya Penyuluh. } \\
\text { Peran mereka disini sebagai } \\
\text { konsultan bagi semua aspek usaha } \\
\text { tani, dengan kata lain mereka } \\
\text { memberi pengarahan dan wawasan } \\
\text { bagi para petani agar memiliki } \\
\text { peningkatan dalam hasil usahanya } \\
\text { dan tingkat kehidupannya. }\end{array}$ \\
\hline $\begin{array}{l}\text { Agricultural extension's role } \\
\text { in Indonesia }\end{array}$ & $\begin{array}{l}\text { Bitmap } \\
\text { Vector } \\
\text { Text }\end{array}$ & $\begin{array}{l}: \text { - } \\
\text { : farmer, Indonesian flag, } \\
\text { agricultural extension } \\
\text { : "Penyuluh, Budidaya, } \\
\text { Fasilitator, Wawasan } \\
\text { Wirausaha, komunikasi dan } \\
\text { informasi teknologi" }\end{array}$ & $\begin{array}{l}\text { Narration: Di era sekarang, petani } \\
\text { Indonesia sangat membutuhkan } \\
\text { penyuluh yang memiliki kemampuan } \\
\text { beragam, seperti kemampuan } \\
\text { budidaya, sebagai fasilitator antar } \\
\text { petani dan pakar di bidangnya, } \\
\text { memliki wawasan wirausaha, dan } \\
\text { menguasai komunikasi dan informasi } \\
\text { teknologi. }\end{array}$ \\
\hline
\end{tabular}

The next stage was production, which entailed characterization, sound arrangement, animation, and rendering. Characterization is conducted by creating a character. Building and developing a character is not just a matter of drawing a figure; rather, each character must also have its own form, personality, features, and behavior (Ranang, Basnendar, \& Asmoro, 2010). Background music and narration were used to tell the story presented in this video. The narrator's voice was recorded using a microphone device. The next step was animating, or giving animation or movement to images. The source of the pictures used in this video was " 30 flat concepts for science"(n.d.), which was taken from https://www.freepik.com (Fig. 2). The pictures were reprocessed through the tracing process. Table 2 shows the source and result pictures. The software programs used to make this video were Adobe After Effects CS6 and Sony Vegas Pro 14. Following the animation, the video was subjected to the rendering process, which involved combining all video files into a single unit. 


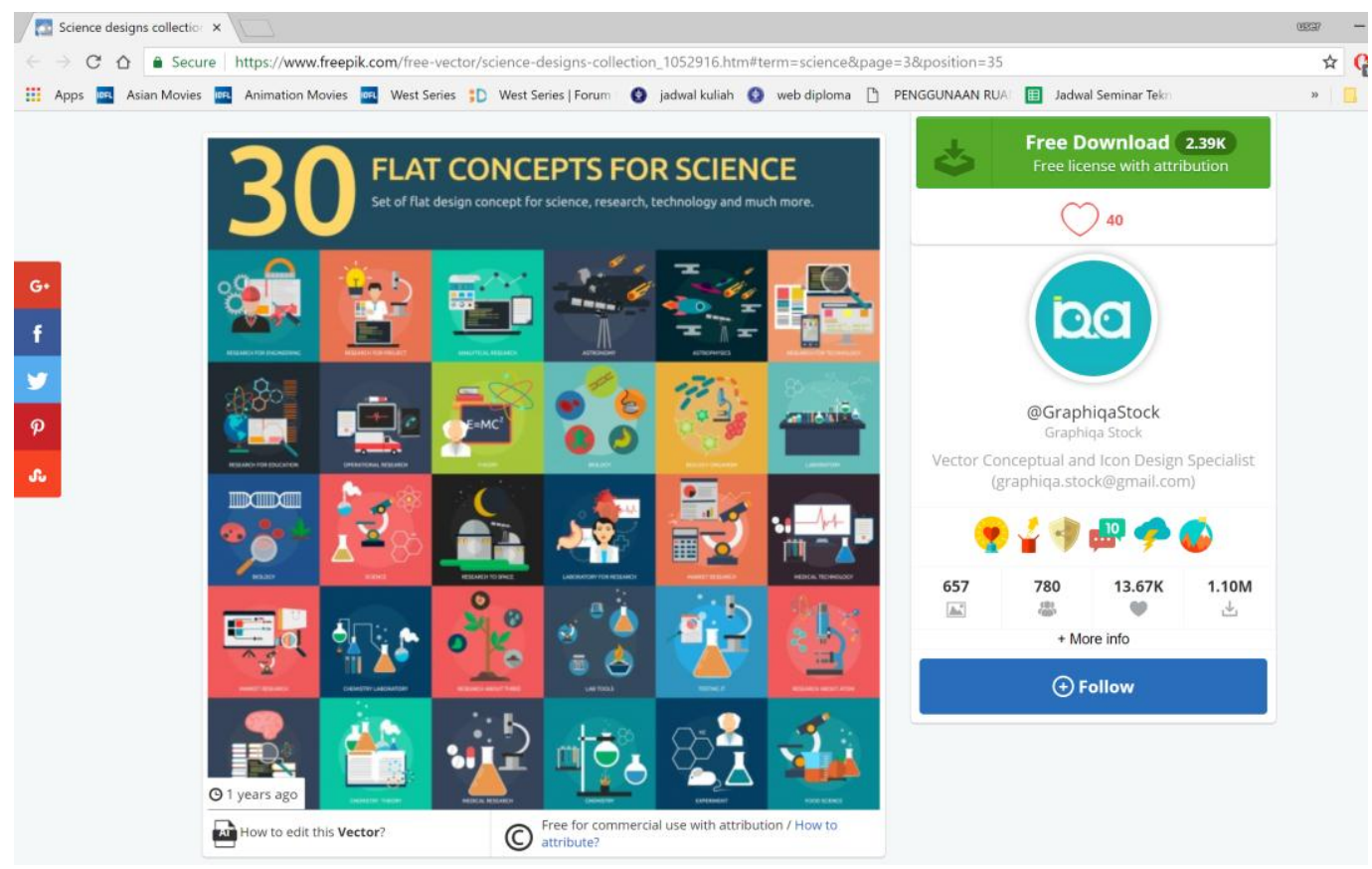

Fig. 2. Source pictures.

(source: https://www.freepik.com/free-vector/science-designs-collection_1052916.htm\#term =science\&page=3\&position=35)

Table 2. Result pictures.

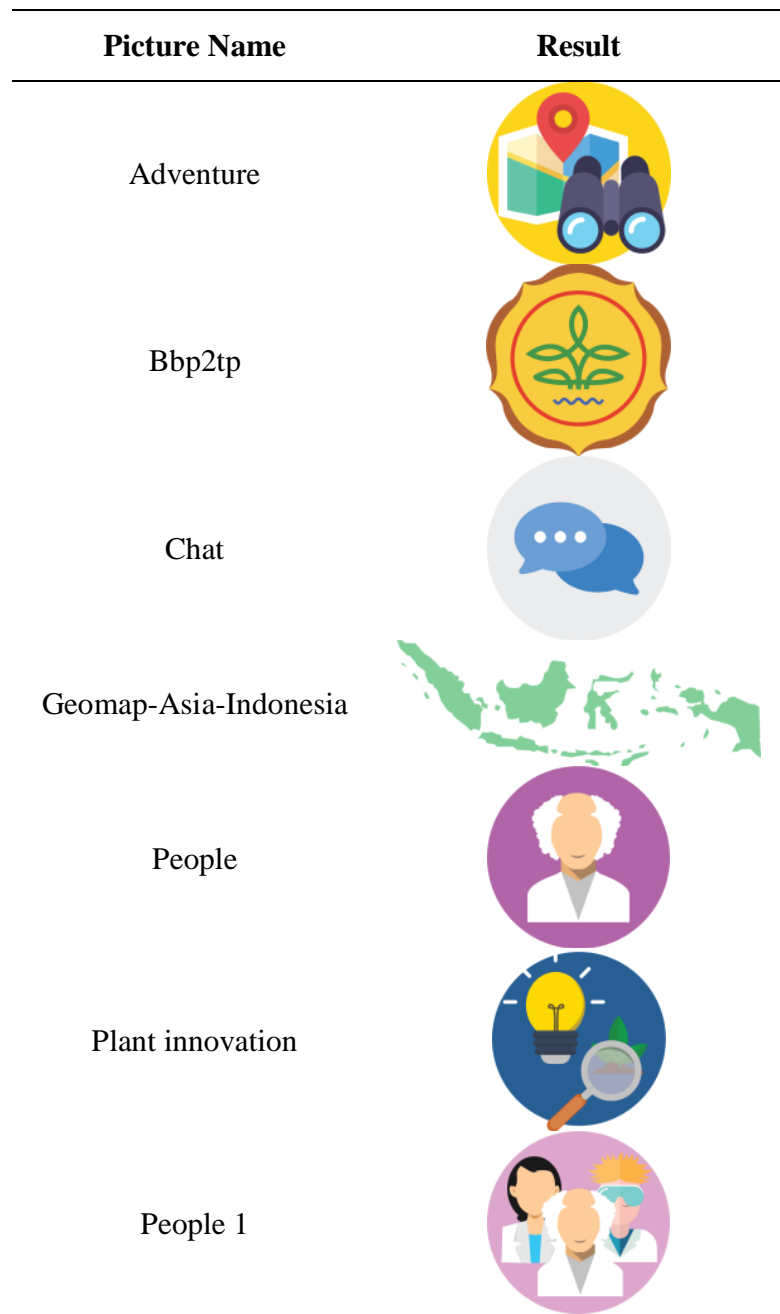

Continue Table 2. Result pictures 


Picture Name

Post production was the final stage, during which the video was reviewed and checked. Videos that went through the rendering process were re-checked for compatibility with the storyline. Following the video matching, the video was uploaded to the IAARD channel for publication and set to run in the agrocinema.

\section{Results and Discussion}

The agricultural extension, plant breeder, and plant researcher animation video is three minutes and 11 seconds long. Table 3 presents the screenshots for the video's scenes.

Table 3. Animation video screenshots

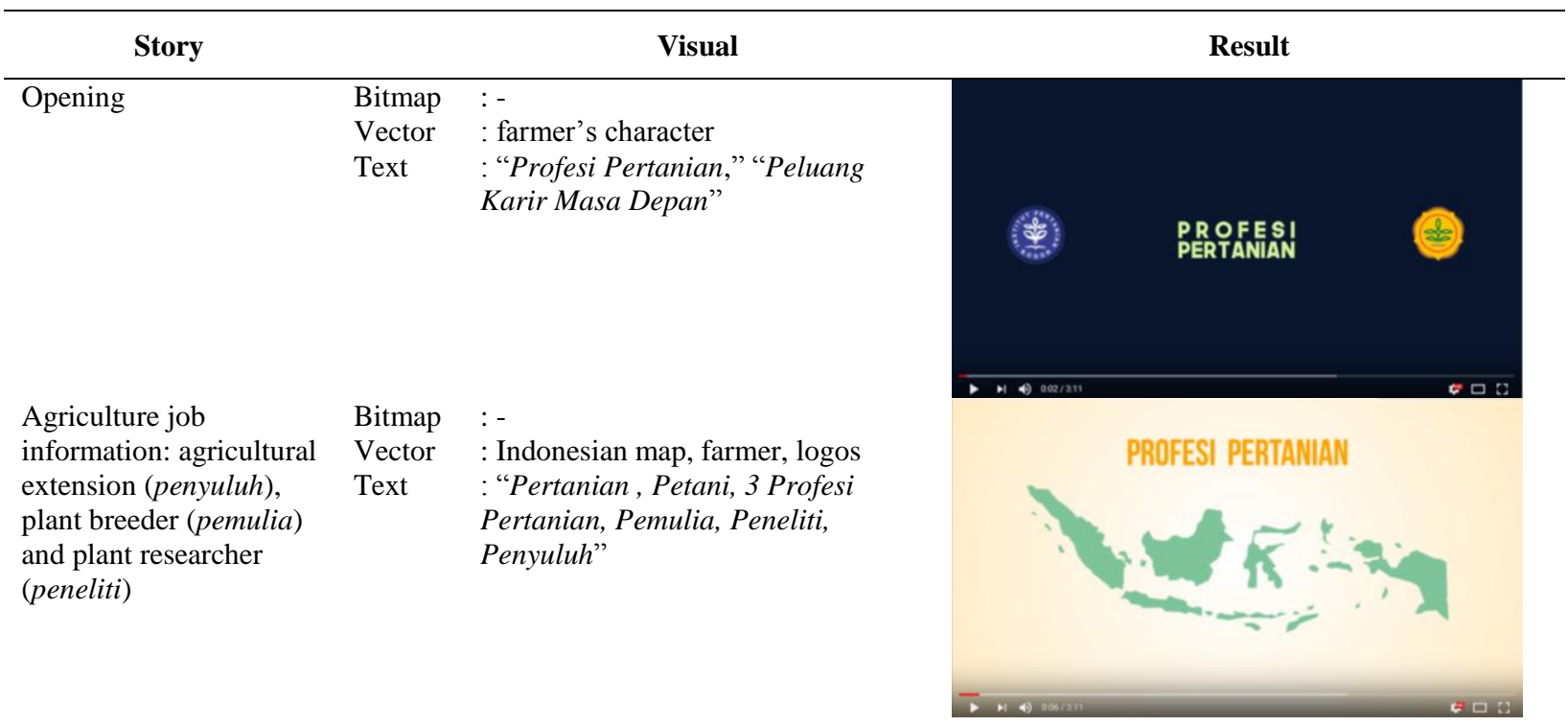


Continue Table 3. Animation video screenshots

\section{Story}

Description of plant breeders

Description of plant researchers

The work of researchers: nanotechnology

Plastic, the result of nanotechnology

Description of agricultural extension

$\begin{array}{ll} & \text { Visual } \\ \text { Bitmap } & :- \\ \text { Vector } & \text { : plant breeder, workspace for plant } \\ & \text { breeder } \\ \text { Text } & \text { : "pemulia" }\end{array}$

Bitmap :-

Vector : researcher, researcher's room, molecule

Text : "peneliti"

\section{Result}

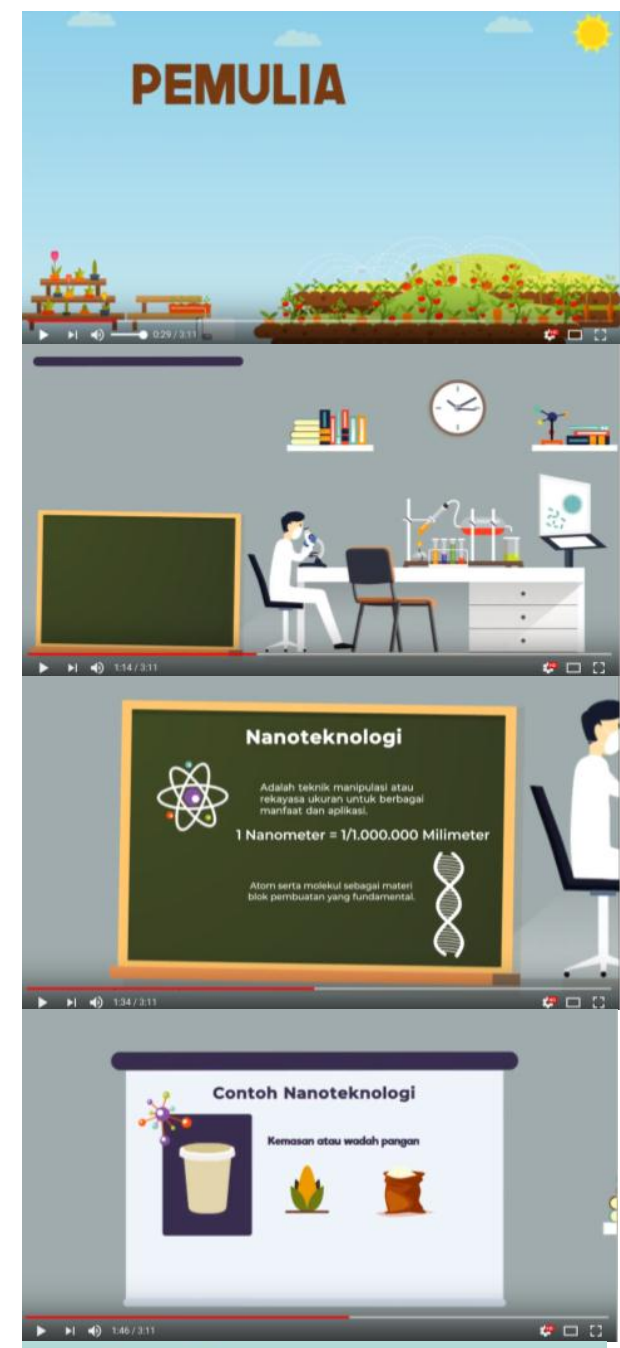

$\begin{array}{ll}\text { Bitmap } & :- \\ \text { Vector } & : \text { farmers, village, farm, money } \\ \text { Text } & : \text { "penyuluh" }\end{array}$

Bitmap :-

Vector : plastic packaging, trees, checklist, coin

Text : "nanotechnology, canggih, praktis"

Agricultural extension's role in Indonesia

Bitmap :

Vector : farmer, Indonesian flag, agricultural extension

Text : "Penyuluh, Budidaya, Fasilitator, Wawasan Wirausaha, komunikasi dan informasi teknologi"

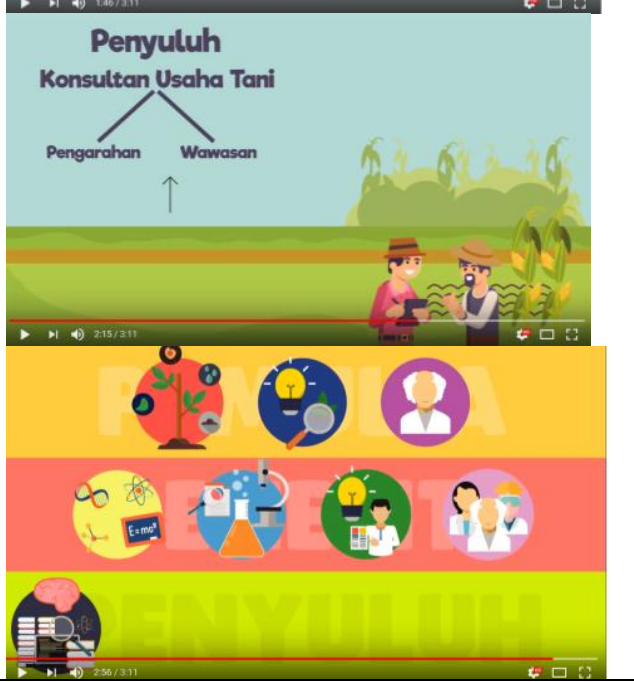

This video consists of eight scenes. The first scene is the opening, which shows the IPB and IAARD logos. The second scene presents the three main agricultural professions in Indonesia, namely agricultural extension, plant breeder and plant researcher. The third scene shows an explanation of the plant breeder job and its tasks. The fourth scene provides an explanation of plant researchers. It also shows nanotechnology animation. Examples of research results in the field of nanotechnology are shown in the sixth scene. Agricultural extension 
is depicted in the seventh scene, and the role of agricultural extension in Indonesia is presented in the final scene.

The distribution of this video is still limited to the IAARD's agrocinema and social media accounts. In addition to the agrocinema, a preview of the video has been launched on IAARD's Instagram account, and the full video can be seen on IAARD's YouTube channel. Although IAARD maintains a large number of social media accounts, it cannot provide information about the three agricultural professions to reach all Indonesian people. IAARD's Instagram account (@bbpengkajianbalitbangtan) is followed by only 1140 users. Therefore, more widely distributed and regular publicity is needed for this information to reach the entire community.

\section{Conclusions}

An agricultural extension, plant breeder, and plant researcher animation video was produced in three stages, namely pre-production, production, and post production. The video's duration is three minutes and 11 seconds. The video format is a cartoon because its target audience comprises elementary and high school students. The video's images are colorful and cheerful. The animation video can be viewed on www.youtube.com and IAARD's Instagram account.

\section{References}

Bestina, S. Hartono, S., \& Syam, A. (2005). Kinerja penyuluh pertanian dalam pengembangan agribisnis nenas di kecamatan tambang, kabupaten kampar. Jurnal Pengkajian dan Pengembangan Teknologi Pertanian, 8(2), $218-231$.

Republic of Indonesia (2004). Peraturan Pemerintah Republik Indonesia Nomor 13 Tahun 2004.

Putra, Y.M. (2016, August 26). Indonesia kekurangan pemulia tanaman. Republika. Retrieved from https://www.republika.co.id/berita/nasional/daerah/16/08/26/ociuj4284-indonesia-kekurangan-pemulia-tanaman

Indonesian Institute of Sciences (LIPI). (2016). Peraturan Kepala Lembaga Ilmu Pengetahuan Indonesia Nomor 1 Tahun 2016 Tentang Pedoman Pemilihan Bidang Kepakaran Peneliti. Retrieved from http://jdih.lipi.go.id/peraturan/2016_perka_1.pdf.

Ranang, A., Basnendar, H., \& Asmoro, N. (2010). Animasi kartun. Jakarta: PT. Indeks.

"30 Flat Concepts for Science" (n.d.) Retrieved from https://www.freepik.com/free-vector/science-designscollection_1052916.htm\#term $=$ science $\&$ page $=3 \&$ position $=35$. 